\title{
Tourism industry in Russia and the EU: are there any consequences of multi-tiered national agenda?
}

\author{
Ilya V. Bogdashev, Anna A. Apalkova, Elena S. Votchenko \\ Kuban State University \\ 149 Stavropolskaya St., Krasnodar, 350040, Russian Federation
}

\begin{abstract}
The aim of the research is to analyze the modern trends and today's development stage of tourism industries in Russia and the EU (Cyprus and the Czech Republic). The article touches a vital topic of contemporary relations among touristic sphere representatives (national and local entrepreneurs), society (consumers), and governmental support (national and local authorities) through the prism of their relations. The authors consider fundamental macro-economic indicators of the tourism industry as an object of the research, whereas mathematical methods of forecasting in tourism studies are as a subject of the research. Besides, the authors underline the main directions of entrepreneurship support as a part of being a successful start-up, in our case, in the touristic industry. Furthermore, it is worth noting the characteristics of the tourism market and the peculiarities of its regulation. In the end, the collaborators have concluded by analyzing the fact that the government regulation of tourism is an effective means of stimulating investment activity, improving the quality of services provided, and solving social problems in terms of the real health of the nation. However, it is crucial to bear in mind that the main directions of state policy should be the stability and competitiveness of the tourist complex.
\end{abstract}

Keywords: tourism industry; public-private partnerships; Gross National Product; GNP; tourism macro-economic indicators; the Russian tourism industry; Cyprus touristic sector; Czech touristic sector; rural tourism

\section{Introduction}

Tourism today includes a wide array of economic and social activities on an international scale and covers all social classes. It is directly related to the development of each modern society and aims at meeting societal needs in a developed culture to create the conditions for advancing understanding and goodwill among different people in order to achieve a better future for humankind.

The contribution of the tourism sector is beneficial for a country's economy due to either its influence on each sector or the foreign exchange sector, like:

- the employment sector and especially in the tourist periphery, with the direct consequence of restraining the tendency to immigrate and keeping the population in its place;

(C) Bogdashev I.V., Apalkova A.A., Votchenko E.S., 2019

(c) () This work is licensed under a Creative Commons Attribution 4.0 International License https://creativecommons.org/licenses/by/4.0/ 
- the business sector, through the expansion of the industrial and agricultural production, to meet the increasing tourist wave, as well as the mobilization of the international and domestic trade and the activities of various service-related industries like transportation, telecommunications, banking, travel agencies;

- the income sector; the tourist income, in addition to contributing to the country's aggregate income, seems to be distributed throughout a broad population stratum; this constitutes a factor of primary importance towards strengthening the development of the periphery;

- the cultural sector; in addition to the improvement of the living standards, there is also a significant boost in their cultural standards;

- the fiscal sector; it must finally be emphasized that the tourist activity exerts beneficial results on public economics and especially at the local level.

The growth potential of international tourist movements depends on several variables that include economic, demographic, technological, psychological, sociopolitical. It is impossible to quantify the interrelationships among all these variables to be able to carry out a complete analysis of trends in international tourism.

The primary variable that influences tourist movements positively is growth in Gross National Product (GNP). GNP growth increases disposable income and hence, the willingness and ability to consume various goods and services, including an increase in tourist demand, whether such a demand refers to the number of arrivals and number of nights spent or to sums of foreign tourist exchange.

Using as a yardstick tourism's appeal as a qualitative social practice, and if current trends continue and come to be realized, then one should expect a more significant increase in demand, both in the near and in the more distant future. In the analysis that follows, an effort is made to identify those variables that influence tourist demand.

Theoretical and practical aspects of regional development competitiveness at different times were discussed in the works of Russian and foreign researchers and scientists such as J. Schumpeter (Schumpeter, 2007), V.A. Andreev (Andreev, 2011), E.L. Dracheva (Dracheva et al., 2005), M.E. Porter (Porter, Kramer, 2006), D.K. Hoover (Hoover, 2005), A.H. Studenmund (Studenmund, 2016), H. Leibenstein (Leibenstein, 1960), and others.

The main goal of the research is the developing of a sophisticated approach for studying mathematical methods in forecasting fundamental macroeconomic indicators of the tourism industry. In work, we applied such methods of econometric modeling and forecasting as modeling using regression equations of fundamental macro-economic indicators of the tourism industry and forecasting using regression equations of fundamental macro-economic indicators of the tourism industry. The next tasks achieve the mentioned goal: to study characteristics of the tourism market and peculiarities of its regulation; to find out theoretical foundations of the organization of tourism support and development in the regions of Russia; to study current state of the tourism industry (in whole world and in each country separately); to make an analysis of the market of tourism industry; to analyze the macroeconomic indicators in the tourism industry (the tourism contribution to GDP); to reveal the problems of government policy for tourism sector; to suggest and recommend measures for improving the government policy for tourism sector. 
As for the empirical base of the research, it is made up of statistic books, balance reports, various open statistic links. The theoretical and methodological base is made up of scholar and scientific works of Russian and foreign scientists on the problems of forecasting fundamental macroeconomic indicators of the tourism industry.

\section{Characteristics of the tourism market and peculiarities of its regulation}

The marketing of tourist product has specific characteristics. Although general principles of marketing could apply to market the product, there are individual differences in approach. These differences are because of the peculiar character of the tourist products. Some unique characteristics of tourist products are as follows (Brunt et al., 2012):

1. Tourism is an intangible product. Tourism is related to service, facility, pleasure, leisure. Which is not possible to visualize.

2. Ownership of the tourist product is non-transferable. In tourism, buying and selling of a product does not mean buying things like other properties. It is buying or selling the service. In the process of buying and selling of the tourism product, no transfer of ownership of goods is involved as compared to a tangible product.

3. Production and consumption are closely interrelated. Production of the tourism product is not to create a new item. It is related to the idea. Tourism product is the amalgamation of attraction, facilities, and accessibility. The travel agents who sell the product neither produce them nor own them. The travel agent cannot store them. Production can only take place and can only be completed if the customer is present. Most of the tourist services cannot be consumed in a time difference. Once consumption starts, it cannot be stopped, interrupted, or modified. The customer cannot inspect, compare, or try before deciding to buy the tourism product.

4. Tourism is an assembled product. A single enterprise can not provide the tourist product. Each of the components of a tourism product is highly specialized, and all these combined make the final product. The tourist product is not an airline or rail seat or a visit to historical sites but rather a combination of many components, which together make a complete product. In tourism, each of the components of the tourist product is sold as an individual product. Airline tickets, hotels, resorts have their own sales outlets. Because of these peculiar characteristics, a coordinated effort is required in tourism marketing.

5. The tourism product does not move. The tourism product cannot be transported. It does not move to the customer, but the customer needs to move to the product. As an attraction, hotels do not move. Transport moves, but it moves to its destination only. The customer must get it to enjoy it.

6. The demand for tourism products is volatile. The demand for tourism products is influenced by different factors such as season, economy, politics, religion, and other special events. The seasonal change dramatically affects demand. Many tourists' areas have a short season. The seasonal business creates unemployment, develops passive investment in staff, transport, office rent, and increases the cost of production. 
7. Wide coverage. Marketing of general product may be limited, or producers can limit their sales campaign and marketing to the local area but in tourism, it must be done outside or in different locations where tourism product is produced, because tourists are the outsiders.

8. A luxurious concept. Tourism product being leisure, pleasure, and comfort is the most luxurious concept, so it must be marketed. In the modern world of mass tourism, it has become more critical to be marketed than before.

The complex functioning of the tourism industry organizations lies in the fact that the assessment of the quality of tourist services by the consumer is entirely subjective and depends on various factors: general economic, cultural and sociopsychological, socio-demographic, personal and behavioral.

The tourism industry operates within a developed legal and regulatory framework that the players in this industry need to adhere to in the course of offering their services. The authority strives to deepen and broaden tourism by developing and implementing a regulatory framework that ensures fairness, orderliness, and high-quality service in the industry. The regulatory framework of the authority comprises the following (Krivoruchko, 2003):

- The Tourism Act 2011; The Tourism Act No. 28 of 2011 was enacted to provide for the development, management, marketing and regulation of sustainable tourism and tourism-related and services and connected services;

- The Tourism Regulatory Authority (TRA) Regulations 2014, according to section 122 of the Tourism Act 2011, Tourism Regulatory Authority Regulations 2014, were formulated and gazette to prescribe matters related to the regulation of the tourism sector and operations of the authority. A vital function of TRA as per the Tourism Act is to: "register, license, and grade all sustainable tourism and tourist-related activities and services including cottages and private residences engaged in guest house services."

In doing so, the need was found to create, in the Regulations, the Standards, and Classification Committee. This would (amongst other functions) carry out the following: undertake overall supervision and guidance of National Tourism Standardization and Classification exercise of all tourism activities and services; oversee the development of standards for all tourism enterprises and activities; provide guidance on regular training and refresher courses for the trained professional assessors to improve their competency in grading/quality assurance system.

Tourism, as defined in 1981 by the International Scientific Association of Tourism Experts in terms of "particular activities chosen and undertaken outside the home," has many manifestation forms. These were classified in the year 1994, in the "Recommendations Referring to Tourism Statistics" by the United Nations, according to several criteria that influence the tourism phenomenon aspects (Box et al., 2008).

The conceptual framework of tourism in the Russian Federation was founded in 1996 in the law "Based on tourist activity." From 01.06.2007, the Federal Law dated 05.02.2007 No. 12-FL "On Amendments to the Federal Law 'On the Basics of Tourism Activities in the Russian Federation" " comes into force. The law clarifies the basic concepts used in the Federal Law "On the basis of tourist activity": 
"Tourism - temporary trips (travels) of the Russian Federation citizens, foreign citizens and stateless people (hereinafter referred to as persons) from permanent residence for medical, recreational, educational, physical and sporting, professional, business, religious and other purposes without activities related to the receipt of income from sources in the country (place) of temporary residence."

One of the possible schemes of interaction between performers and consumers of tourism services is presented in Figure 1. A complex system of organizing the production of such a product is called a tourism infrastructure.

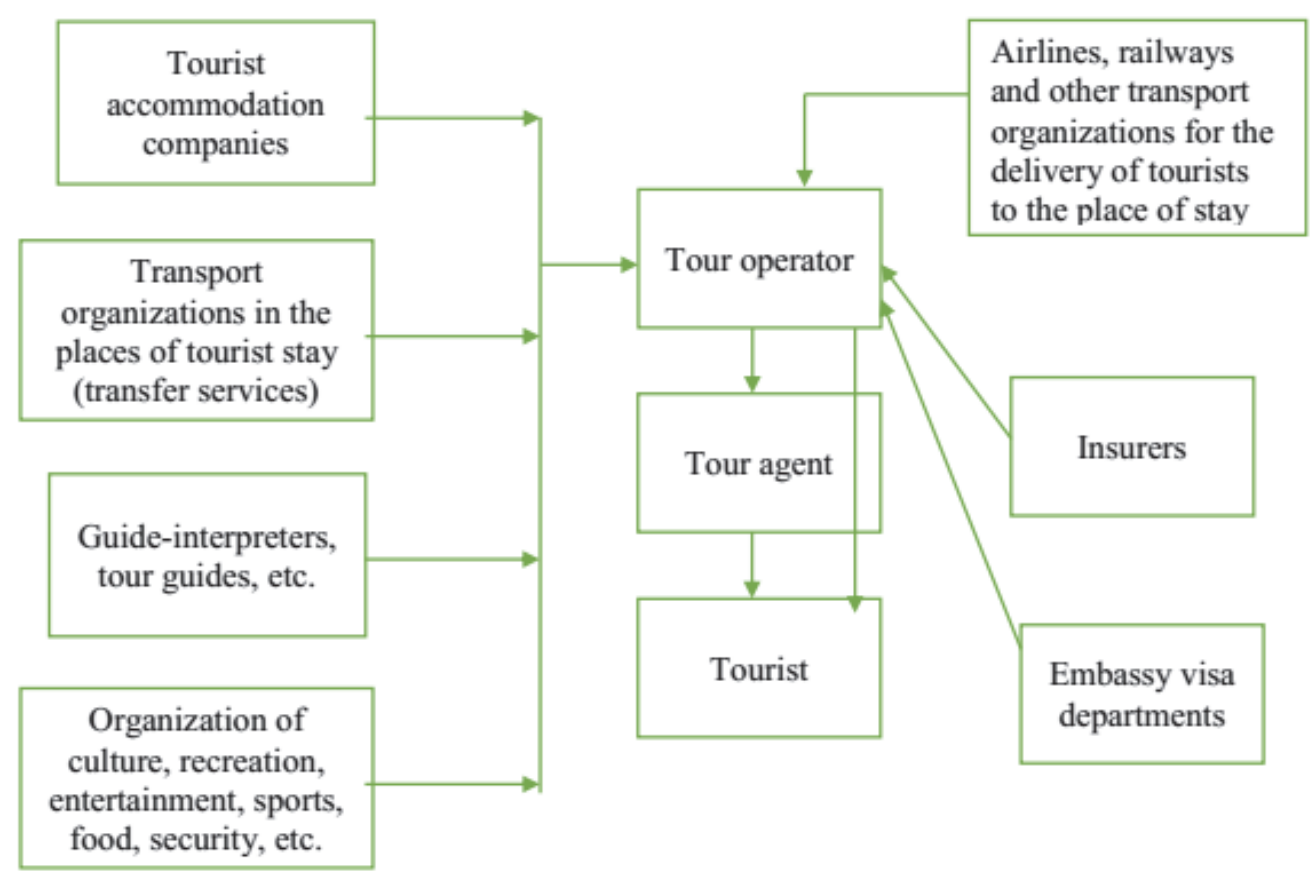

Figure 1. The interaction of individual subjects of the tourist market

Source: built by the authors.

Tourist infrastructure is a complex of existing facilities and networks for industrial, social, and recreational purposes, intended for the functioning of the tourism industry. Tourism infrastructure is an integral part of the tourism industry (Figure 2), which includes two elements. The first element is the hospitality industry. To the hospitality industry, it is advisable to refer to the structure needed for high-quality guest service.

The second element of the tourism industry is the infrastructure component, which is a three-level system. The production infrastructure represents the first level of tourism infrastructure - a complex of existing facilities, buildings, transport networks, systems not directly related to the production of tourist products (as opposed to the structures of the two subsequent levels), but necessary for the provision of tourist services: transport, communications, energy, utilities, finance, insurance, security. 


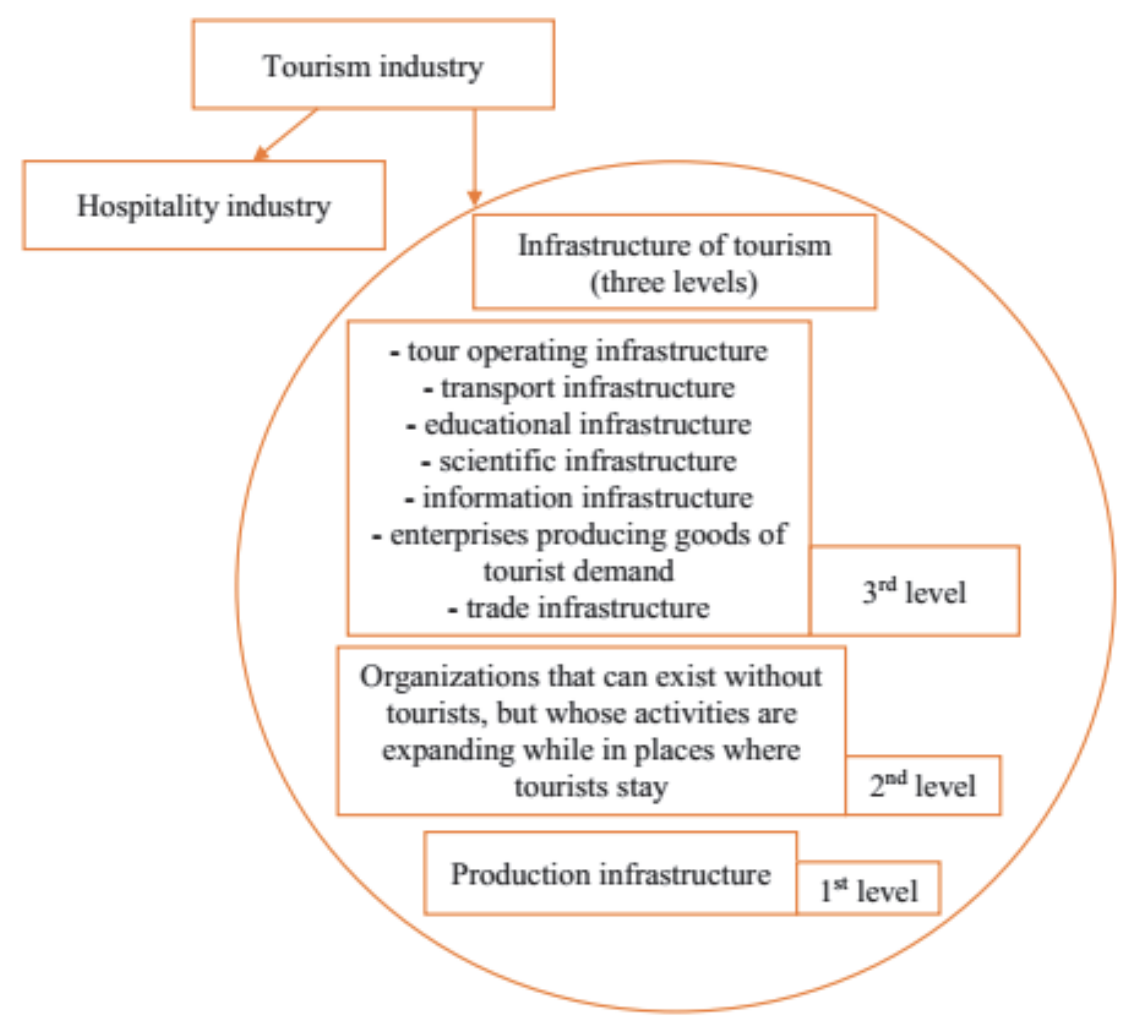

Figure 2. Tourism infrastructure as part of the tourism industry

Source: built by the authors.

The second and third levels of the tourist infrastructure form the enterprises and organizations directly involved in tourism activities and the formation of tourist products. The second level includes those structures that can exist without tourists, but the activities of which expand when they are located in the places where tourists stay. These are car rental companies, taxis, cafes and restaurants, sports clubs, museums, theaters and cinemas, exhibition halls, circuses, casinos.

The following elements represent the third level: infrastructure tour operating - tourist firms involved in the organization and sale of tourist trips; transport infrastructure - transport organizations engaged in tourist transportation; educational infrastructure - educational institutions for the training and advanced training of specialists in the tourism industry; information infrastructure - booking and reservation system; information and advertising services; tourism authorities government agencies whose functions include managing the development of tourism in the country and in the regions; scientific infrastructure - research organizations involved in the collection and processing of statistical data on tourism, the preparation of scientific forecasts and research in the field of economics and sociology of tourism; enterprises producing goods of tourist demand; trade infrastructure retailers selling goods of tourist demand.

Summing up, it should be noted that tourism itself has an impact on all aspects of the development of the country as a whole and individual region, in particular, contributing to increasing income, improving infrastructure, solving 
the problem of employment by creating new jobs, strengthening interstate and interregional relations.

For Russia, a regional approach to tourism is essential because of the vast territory and the enormous natural, social, and economic differences.

\section{The current state of the tourism industry}

Over the decades, tourism has experienced continued growth and deepening diversification to become one of the fastest-growing economic sectors in the world. Modern tourism is closely linked to development and encompasses a growing number of new destinations. These dynamics have turned tourism into a critical driver for socio-economic progress.

Today, the business volume of tourism equals or even surpasses that of oil exports, food products, or automobiles. Tourism has become one of the major players in international commerce and represents, at the same time, one of the primary income sources for many developing countries. This growth goes hand in hand with an increasing diversification and competition among destinations. This global spread of tourism in industrialized and developed states has produced economic and employment benefits in many related sectors - from construction to agriculture or telecommunications.

The contribution of tourism to economic well-being depends on the quality and the revenues of the tourism offer. UNWTO assists destinations in their sustainable positioning in ever more complex national and international markets. As the UN agency dedicated to tourism, UNWTO points out that particularly developing countries stand to benefit from sustainable tourism and acts to help make this a reality.

Current developments and forecasts according to actual statistics data are the following: international tourist arrivals grew by $4.6 \%$ in 2015 to 1,184 million; in 2015, international tourism generated US\$ 1.5 trillion in export earnings; UNWTO forecasts a growth in international tourist arrivals of between 3.5 and $4.5 \%$ in 2016; by 2030 , UNWTO forecasts international tourist arrivals to reach 1.8 billion, according to the UNWTO Tourism Towards 2030 (UNWTO General Assembly, 2011).

The Global Tourism industry gained a total of $\$ 1.5$ trillion in 2018 , with revenue rising at an annualized rate of $0.2 \%$ over the five years to 2018 . Global tourism has performed well during the five years, with emerging economies continuing to stimulate growth.

In the table Table 1, we show the leading indicators of the tourism industry in Russia. From table, we can see the growth rate of different indicators in Russia. Almost all indicators have negative dynamics, except Direct Contribution to Employment, indicating that by 2017 , the number of job places in the tourism sphere had been expanded. One more indicator shows positive dynamic despite negative meaning - Expenditures because Rate of growth -4.7 , in this case, shows that costs were reduced. 
Table 1

The leading indicators of the tourism industry in Russia

\begin{tabular}{|c|c|c|c|c|c|c|c|c|}
\hline \multirow{2}{*}{ Main indicators } & \multicolumn{7}{|c|}{ Years } & \multirow{2}{*}{$\begin{array}{c}\text { Rate of } \\
\text { growth, } \\
\%\end{array}$} \\
\hline & 2011 & 2012 & 2013 & 2014 & 2015 & 2016 & 2017 & \\
\hline $\begin{array}{l}\text { Travel \& Tourism } \\
\text { Direct Contribution } \\
\text { to GDP, \$ million }\end{array}$ & 25000 & 26000 & 27000 & 26000 & 17000 & 16000 & 19000 & -24.0 \\
\hline $\begin{array}{c}\text { Expenditures } \\
\text { (current US \$ } \\
\text { million) }\end{array}$ & 37343 & 48096 & 59504 & 55383 & 38434 & 27653 & 35585 & -4.7 \\
\hline $\begin{array}{l}\text { Travel \& Tourism } \\
\text { Direct Contribution } \\
\text { to Employment, } \\
\text { a thousand people }\end{array}$ & 851.8 & 808.5 & 814.2 & 838.3 & 807.8 & 850.1 & 854.6 & 0.33 \\
\hline $\begin{array}{l}\text { Inbound Tourism } \\
\text { Indicators, } \\
\$ \text { million }\end{array}$ & 8830 & 11328 & 10759 & 11988 & 11759 & 8420 & 7788 & -11.8 \\
\hline $\begin{array}{l}\text { Receipts (current } \\
\text { US\$ million) }\end{array}$ & 16961 & 17876 & 20198 & 19451 & 13204 & 12820 & 14983 & -11.6 \\
\hline
\end{tabular}

Source: All data were taken from World Data Atlas. https://knoema.com (accessed: 05.05.2019).

Let us compare it with the Cyprus touristic sphere, presented in Table 2.

Table 2

The leading indicators of the tourism industry in Cyprus

\begin{tabular}{|c|c|c|c|c|c|c|c|c|}
\hline \multirow{2}{*}{ Main indicators } & \multicolumn{7}{|c|}{ Years } & \multirow{2}{*}{$\begin{array}{c}\text { Rate of } \\
\text { growth, } \\
\%\end{array}$} \\
\hline & 2011 & 2012 & 2013 & 2014 & 2015 & 2016 & 2017 & \\
\hline $\begin{array}{l}\text { Travel \& Tourism } \\
\text { Direct Contribution } \\
\text { to GDP, \$ million }\end{array}$ & 1000 & 1000 & 2000 & 1000 & 1000 & 1000 & 2000 & 100.0 \\
\hline $\begin{array}{l}\text { Travel \& Tourism } \\
\text { Direct Contribution } \\
\text { to Employment, } \\
\text { a thousand people }\end{array}$ & 22.4 & 24.4 & 26.5 & 25.3 & 23.5 & 24.7 & 26.1 & 16.5 \\
\hline $\begin{array}{l}\text { Inbound Tourism } \\
\text { Indicators, } \\
\$ \text { million }\end{array}$ & 2160 & 2554 & 2599 & 2893 & 2844 & 2487 & 2762 & 27.8 \\
\hline $\begin{array}{l}\text { Receipts (current } \\
\text { US \$ million) }\end{array}$ & 2707 & 2732 & 3020 & 2920 & 2481 & 2757 & 3128 & 15.5 \\
\hline $\begin{array}{c}\text { Expenditures } \\
\text { (current US \$ } \\
\text { million) }\end{array}$ & 1730 & 1687 & 1621 & 1771 & 1439 & 1604 & 1781 & 2.95 \\
\hline
\end{tabular}

Source: All data were taken from World Data Atlas. https://knoema.com (accessed: 05.05.2019).

Almost all indicators have a positive dynamic of growth, except Expenditures, indicating that this sphere of tourism needs to be improved by governmental policy. 
Then to study the situation in the Czech Republic, gathered from Table 3.

The leading indicators of the tourism industry in the Czech Republic

\begin{tabular}{|c|c|c|c|c|c|c|c|c|}
\hline \multirow{2}{*}{ Main indicators } & \multicolumn{7}{|c|}{ Years } & \multirow{2}{*}{$\begin{array}{l}\text { Rate of } \\
\text { growth } \\
\%\end{array}$} \\
\hline & 2011 & 2012 & 2013 & 2014 & 2015 & 2016 & 2017 & \\
\hline Travel \& Tourism & & & & & & & & \\
\hline $\begin{array}{l}\text { Direct Contribution } \\
\text { to GDP, \$ million }\end{array}$ & 6000 & 6000 & 5000 & 5000 & 5000 & 5000 & 6000 & 0 \\
\hline $\begin{array}{l}\text { Travel \& Tourism } \\
\text { Direct Contribution } \\
\text { to Employment, } \\
\text { a thousand people }\end{array}$ & 249.7 & 226.4 & 207.3 & 211.8 & 213.5 & 218.4 & 223.4 & -10.5 \\
\hline $\begin{array}{l}\text { Expenditures } \\
\text { (current US \$ } \\
\text { million) }\end{array}$ & 4876 & 4556 & 4698 & 5173 & 4819 & 4963 & 5518 & 13.1 \\
\hline $\begin{array}{l}\text { Receipts (current } \\
\text { US \$ million) }\end{array}$ & 8930 & 8174 & 7792 & 7614 & 6766 & 7041 & 7693 & -13.8 \\
\hline $\begin{array}{l}\text { Inbound Tourism } \\
\text { Indicators, \$ million }\end{array}$ & 7172 & 8096 & 7456 & 7042 & 6822 & 6056 & 6308 & -12.0 \\
\hline
\end{tabular}

Source: All data were taken from World Data Atlas. https://knoema.com (accessed: 05.05.2019).

In the Czech Republic, the picture is almost the same as in the Russian Federation because only expenditures by international visitors have dynamic growth, but in our case, it is the bad sign. According to these indicators, we can track a tendency of growth or decrease during the years.

\section{Analysis of macro-economic indicators in the tourism industry}

Travel \& Tourism is an essential economic activity in most countries around the world. As well as its direct economic impact, the sector has significant indirect and induced impacts too. The direct contribution of Travel \& Tourism to GDP reflects the "internal" spending on Travel \& Tourism (total spending within a particular country on Travel \& Tourism by residents and non-residents for business and leisure purposes) as well as government "individual" spending - spending by government on Travel \& Tourism services directly linked to visitors, such as cultural (e.g. museums) or recreational (e.g. national parks). The direct contribution of Travel \& Tourism to GDP is calculated to be consistent with the output, as expressed in National Accounting, of tourism-characteristic sectors such as hotels, airlines, airports, travel agents, and leisure and recreation services that deal directly with tourists. The direct contribution of Travel \& Tourism to GDP is calculated from total internal spending by "netting out" the purchases made by the different tourism industries. This measure is consistent with the definition of Tourism GDP. 
Therefore, we will analyze the direct contribution of tourism to GDP (\% share) in the Russian Federation, Cyprus, and the Czech Republic separately. The curve in Figure 3 shows the change of GDP percent share within 12 years. In 2017, travel and tourism direct contribution to GDP (\% of GDP) for the Russian Federation was $1.24 \%$. Travel and tourism's direct contribution to GDP (\% of GDP) of the Russian Federation fell gradually from $1.68 \%$ in 1998 to $1.24 \%$ in 2017.

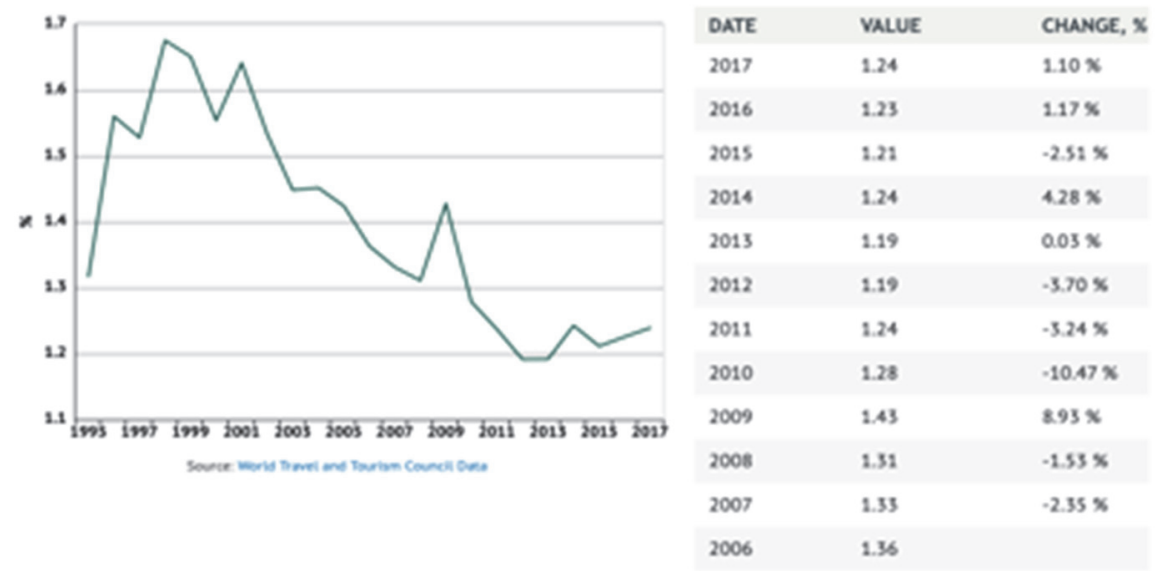

Figure 3. Direct contribution of the Russian Federation to GDP, \% share

Source: All data were taken from World Data Atlas. https://knoema.com (accessed: 05.05.2019).

The situation in the Czech Republic is quite better (Figure 4). They have an average percentage of the direct contribution of tourism to GDP by about $2.5-3 \%$. In 2017, travel and tourism's direct contribution to GDP (\% of GDP) for the Czech Republic was $2.58 \%$. Though the Czech Republic travel and tourism direct contribution to GDP (\% of GDP) fluctuated substantially in recent years, it tended to decrease through the 1998-2017 period ending at $2.58 \%$ in 2017.

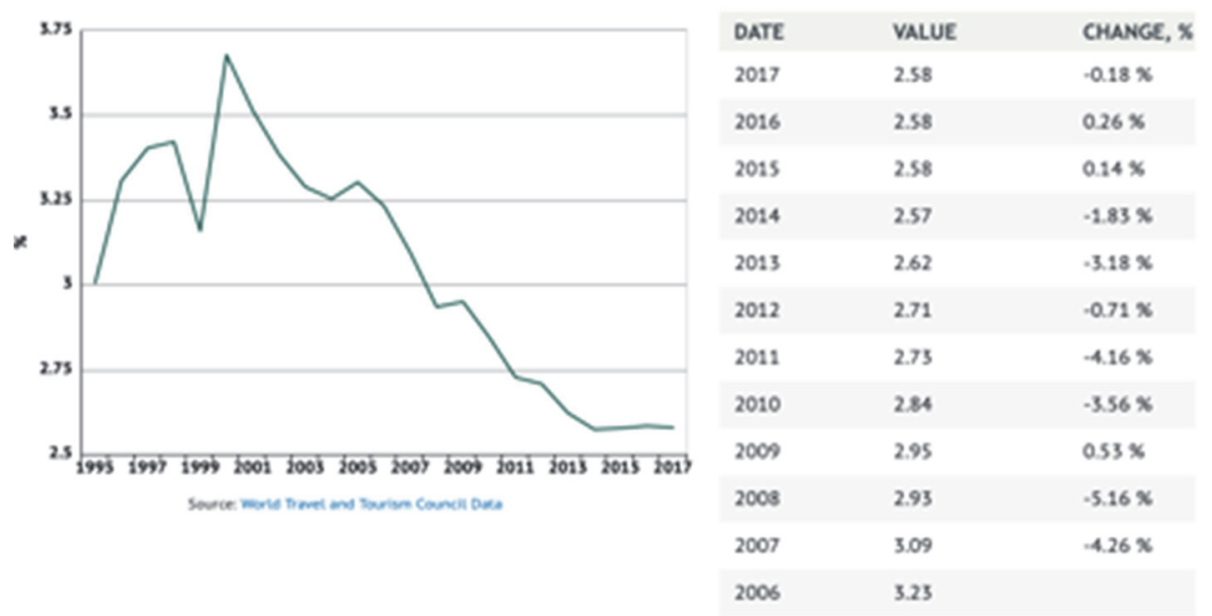

Figure 4. Direct contribution of the Czech Republic to GDP, \% share

Source: All data were taken from World Data Atlas. https://knoema.com (accessed: 05.05.2019). 
Cyprus shows the highest indicators of the direct contribution of tourism to GDP, and it is not accidentally. Cyprus' economy has extreme dependence from tourism because it is an island state, and most of the local population earn money this way. By the way, we can see from Figure 5 that there was a quite long recession during the 2000-2009 years. Only after the 2009 year, the direct contribution of tourism to Cyprus GDP has grown. Cyprus travel and tourism direct contribution to GDP (\% of GDP) was at the level of $7.31 \%$ in 2017 , up from $6.84 \%$ the previous year.

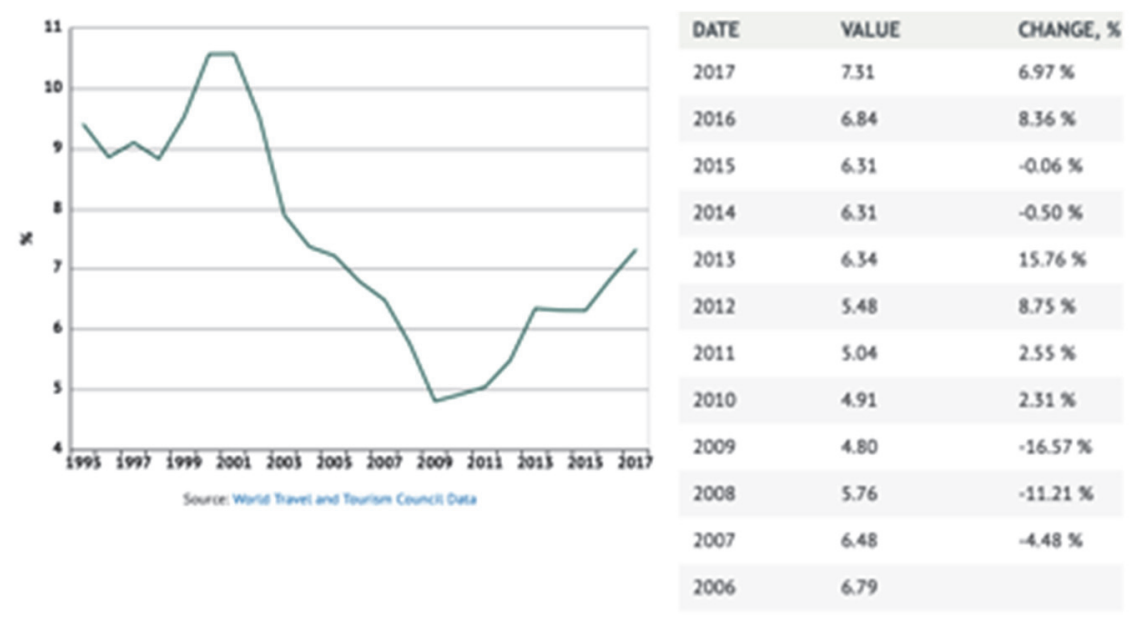

Figure 5. Direct contribution of Cyprus to GDP, \% share

Source: All data were taken from World Data Atlas. https://knoema.com (accessed: 05.05.2019).

\section{Revealing the problems of government policy for the tourism sector}

Tourist business in Russia is in the stage of profound structural reorganization, institutional formation, the formation of intra-industry, inter-industry, interregional, and foreign economic relations. This entirely relates to the process of the formation of tourist infrastructure, the corresponding segment of the labor market, the system of state regulation of tourist activity (Song, Li, 2008).

At present, Russia, as a country developing international tourism, occupies a very modest place in the global tourism market. The share of tourists entering Russia is approximately $1 \%$ of the global tourist flow. This is a low figure, given that cultural Russia's historical and natural potential is much higher than in many countries with traditionally high tourist attendance. In our opinion, this is due to several problems, the key to which is the problem of organization and strategic development tourism as a particular sphere of professional activity at the state level.

Consequently, researchers are faced with the problem of finding such methods for building an effective industry management system that would streng- 
then the market position of each Russian organization engaged in serving tourists, and thereby contribute to the further development of the entire tourism business in Russia, our country's growing into the industry world tourism.

However, it should be noted that in Russia, certain tendencies towards the organization of the state regulation system of tourist activity have already emerged. The implementation of the state policy in the field of conservation and development of tourism is carried out by the Federal Agency for Tourism of the Russian Federation, which is under the jurisdiction of the Ministry of Sport, Tourism and Youth Policy of the Russian Federation. At the same time, the main principle of state regulation of tourist activity is that the state recognizes this area as one of the priority sectors of the Russian economy, contributing to its full development. In particular, the state is actively using such essential tools for regulating the activities of tourist organizations and protecting the rights of consumers of tourist services, such as licensing standardization and certification.

Services on international tourism in Russia at the present stage does not always correspond to designated standards of service, quality assurance services at entry tourism. This happens for several reasons. This is precisely the reason and, at the same time, a consequence of the ineffective system of international business management in the Russian Federation.

World experience demonstrates the feasibility and even the need to divide national tourist administrations into two branches: the first solve global tasks related to the regulatory framework, collecting and processing statistical information, coordinating the activities of tourism enterprises and regions, international cooperation at the regional level, and the second is marketing activities.

The need for separation of powers and duties can be explained by the goals set before the tourist administration authorities. The specialized ministry sees the main goal in the development of international tourism in the formation of a modern, highly efficient, and competitive tourist complex. At the same time, the ministry responsible for marketing activities focuses on creating a positive image of the country in the global tourism market and increasing the attractiveness of the national market for international tourism activities (Song, 2009).

\section{Conclusion: \\ recommendations and further research practice}

Tourism is the most potent economic branch worldwide, with complex functions and multisector implications. With about one hundred thousand employees worldwide, tourism stands out as the most important employer. In this context, rural tourism has emerged and developed, embracing all the tourism activities in the rural areas, with the purpose to put into value the natural and human potential of villages. This is considered as "the meeting place" of the rural culture with the urban culture, which is much more sensitive to nature. Rural tourism is also an occupational alternative for the rural labor force, a modality for the diversification of the economic activities, generating alternative incomes, and it represents a factor of the rural population's stabilization. 
In the fragile and pristine areas, which are most often protected areas, the ecotourism or ecological tourism can also be developed, which is a form of sustainable tourism, whose goal is to supply high-quality tourism services in the conditions of protecting the natural areas and stimulating local economic development.

The support to tourism infrastructure and services in the rural area is necessary out of two reasons: firstly, for the creation and promotion of competitive tourism, and secondly, for setting up local networks for the promotion and supply of these services with the active involvement of the rural population, mainly of women and young people. There are very few methods to measure the success and profitability of investments in tourism, due to the semi-informal nature of activities, the poorly organized promotion and marketing, mainly at the county and local level, which makes it difficult for the entrepreneurs/operators to penetrate on the market and develop their businesses correspondingly.

The development of an economic activity needs finance, which can be provided from own resources accumulated in time or borrowed; support provided by the business partners, which can finance the entrepreneur's business by the supply of equipment, raw materials and materials in advance, on the condition of the subsequent payment of their cost, also named commercial credit (this type of credit is practiced as a rule between enterprises that have long and stable commercial relations); bank credit or credit from other financial institutions; national, European and international programs oriented towards the support of small and medium-sized enterprises.

The development of micro-enterprises, as well as of the small and mediumsized enterprises in the touristic industry, will play an essential role in the economy, where it represents a significant source for obtaining incomes and for the promotion of entrepreneurial skill, innovation, and job creation.

\section{References}

Ahmed Z.U. (1991). The influence of the components of a state's tourism image on product positioning and strategy./ Tourism Management, 12, 331-340.

Aldrich J. (1989). Autonomy. Oxford Economic Papers, 41(1), 15-34.

Andreev V.A. (2011). Gosudarstvennaya podderzhka malogo biznesa [State support of small business]. Moscow. (In Russ.)

Box G.E., Jenkin G.M., Reinsel G.C. (2008). Time Series Analysis: Forecasting and Control. $4^{\text {th }}$ ed. Hoboken, NJ: Wiley.

Brunt L., Lerner J., Nicholas T. (2012). Inducement Prizes and Innovation. The Journal of Industrial Economics, 60(4), 657-696.

Chao Hsiang-Ke. (2005). A Misconception of Semantic Conception of Econometrics? Journal of Economic Methodology, 6, 93-97.

Dracheva E.L., Zabaev J.V., Ismaev D.K. (2005). Ekonomika i organizatsiya turizma [Economy and the organization of tourism]. Moscow. (In Russ.)

Dymchenko A.S. (2000). Marketing i logistika v sisteme gosudarstvennoy sanatorno-kurortnoy sfery [Marketing and logistics in system of the government sanatorium sphere]. Sochi. (In Russ.)

Federal Law from 24.07.2007 No. 209-FZ. On the development of small and medium enterprises in the Russian Federation in the reduction from 27.12.2009. (2007, 30 July). Meeting of the legislation of the Russian Federation, (31), 4006.

Hoover D.K. (2005). The Methodology of Econometrics. Palgrave Handbooks of Econometrics. Vol. 1: Theoretical Econometrics (pp. 12-18). 
Krivoruchko L.V., Krivoruchko V.I. (2003) Rynochnyye mekhanizmy upravleniya sanatornokurortnoy sferoy [Market mechanisms of management of sanatorium sphere]. Moscow. (In Russ.)

Leibenstein H. (1960). Economic Backwardness and Economic Growth: Studies in the Theory of Economic Development. John Wiley \& Sons.

Porter M., Kramer M. (2006). Strategy and Society: the Link between Competitive Advantage and Corporate Social Responsibility. Harvard Business Review, 12.

Schumpeter J. (2007). Entrepreneurship, Competitiveness and Local Development (p. 5). Iandoli, Landström and Raffa.

Song H., Li G. (2008). Tourism demand modelling and forecasting - a review of recent research. Tourism Management, 29(2), 203-220.

Song H., Witt S.F., Li G. (2009). The Advanced Econometrics of Tourism Demand. New York. Studenmund A.H. (2016). Using Econometrics: A Practical Guide. $7^{\text {th }}$ Edition. Prentice Hall. UNWTO General Assembly. $19^{\text {th }}$ Session. http://media.unwto.org/sites/all/files/pdf/unwto_2030_ ga_2011_korea.pdf (accessed: 31.05.2019).

Article history:

Received: 01.06.2019

Revised: 10.07.2019

Accepted: 20.08.2019

\section{For citation:}

Bogdashev I.V., Apalkova A.A., Votchenko E.S. (2019). Tourism industry in Russia and the EU: are there any consequences of multi-tiered national agenda? RUDN Journal of Economics, 27(3), 536-550. http://dx.doi.org/10.22363/2313-2329-2019-27-3-536-550

\section{Bio notes:}

Ilya V. Bogdashev, PhD in Economics, Associate Professor, Theoretical Economics Department, Economy Faculty, Kuban State University. E-mail: ilbogdashev@gmail.com Anna A. Apalkova, master student, Marketing and Trading Business Department, Economy Faculty, Kuban State University. E-mail: anna_777_apalkova@mail.ru

Elena S. Votchenko, $\mathrm{PhD}$ in Politics, Marketing and Trading Business Department, Economy Faculty, Kuban State University. E-mail: evotchenko@gmail.com

Научная статья

\section{Индустрия туризма в России и ЕС: есть ли последствия многоуровневой национальной повестки дня?}

\section{И.В. Богдашев, А.А. Апалькова, Е.С. Вотченко}

Кубанский государственный университет|

Российская Федераџия, 350040, Краснодар, ул. Ставропольская, 149

Целью исследования является анализ современных тенденций и современного этапа развития индустрии туризма в России и ЕС (Кипр и Чехия). Статья затрагивает актуальную тему современных отношений между представителями туристической сферы (национальными и местными предпринимателями), обществом (потребителями) и государственной поддержкой (национальными и местными властями) сквозь призму их 
отношений. В качестве объекта исследования авторы рассматривают основные макроэкономические показатели индустрии туризма, а предметом исследования являются математические методы прогнозирования в исследованиях туризма. Кроме того, авторы выделяют основные направления поддержки предпринимательства как части успешного стартапа, в нашем случае - в туристической индустрии. Также стоит отметить особенности туристического рынка и специфику его регулирования. Авторы пришли к выводу, что государственное регулирование туризма является эффективным средством стимулирования инвестиционной деятельности, повышения качества предоставляемых услуг и решения социальных проблем с точки зрения реального здоровья нации. Однако важно иметь в виду, что основными направлениями государственной политики должны быть стабильность и конкурентоспособность туристического комплекса.

Ключевые слова: индустрия туризма; государственно-частные партнерства; валовой национальный продукт; ВНП; макроэкономические показатели туризма; российская индустрия туризма; туристический сектор Кипра; туристический сектор Чехии; сельский туризм

\section{История статьи:}

Дата поступления в редакцию: 01.06.2019

Дата проверки: 10.07.2019

Дата принятия к печати: 20.08.2019

\section{Для цитирования:}

Bogdashev I.V., Apalkova A.A., Votchenko E.S. Tourism industry in Russia and the EU: are there any consequences of multi-tiered national agenda? (Индустрия туризма в России и ЕС: есть ли последствия многоуровневой национальной повестки дня?) // Вестник Российского университета дружбы народов. Серия: Экономика. 2019. T. 27. № 3. C. 536-550. http://dx.doi.org/10.22363/2313-2329-2019-27-3-536-550

\section{Сведения об авторах:}

Богдашев Илья Владимирович, кандидат экономических наук, доцент, доцент кафедры теоретической экономики, экономический факультет, Кубанский государственный университет. E-mail: ilbogdashev@gmail.com

Апалькова Анна Андреевна, магистрант кафедры маркетинга и торгового дела, экономический факультет, Кубанский государственный университет. E-mail: anna_777 apalkova@mail.ru

Вотченко Елена Сергеевна, кандидат политических наук, доцент кафедры маркетинга и торгового дела, экономический факультет, Кубанский государственный университет. E-mail: evotchenko@gmail.com 